\title{
Ogaga Okuyade
}

\section{Narrating Growth in the Nigerian Female Bildungsroman}

\begin{abstract}
The Bildungsroman has been extensively studied in the West, but scholarly works on it in Africa are very few. This could be attributed to the fact that these narratives are sometimes treated as juvenile fiction because of the preponderance of growing-up children in them. I therefore examine how third generation Nigerian female writers subvert and alter the form in an African context to articulate the fact that growth as a universal human experience differs according to contexts and the space where it is negotiated. The paper concentrates mainly on Adichie's Purple Hibiscus, but I shall make passing remarks on Azuah's Sky-High Flames and Atta's Everything Good Will Come, not specifically for the purpose of intertextuality, but to demonstrate how these novels belong to the same tradition. From the plot structure and analysis of texts it becomes clear that the traditional western Bildungsroman has been domesticated within a postcolonial context to appraise narratives of growth. They offer a model of resistance to women's oppression. The Nigerian variant of the Bildungsroman articulated in these novels portrays the struggle for individuation and the negotiations of feminine subjectivity, while concurrently depicting the plight of women in a society plagued by the debilitating forces of patriarchy, and alternatives to that plight.
\end{abstract}

If the prominent Nigerian writers in English in the second half of the twentieth century were males, those of the first decade of the twenty-first century appear to be females. This is not to argue that Nigerian male writers have gone underground, but to indicate that the number of female writers has continued to soar with the passage of time since the 1990s. The most fascinating feature of the narratives this essay deals with is the fact that most of them explore the issue of identity formation. These novels owe this distinction to the innovative, perhaps, rebellious strategies employed by the protagonists to contain the process of re-enacting and sustaining the grand dominant narrative of recircling or reproducing the script constructed for women like most of the mothers who are frustratingly trapped within the confines of domestic spaces. The mothers in these narratives are usually reduced to victims of familial ideology and patriarchal oppression. While the mothers' culturally imposed identity is submerged by the burdens of the mythologies and iconic represen-

The AnaChronisT 16 (Winter 2011): 152-170 ISSN 1219-2589 (print) 
tations of women as subservient, self-sacrificing, chaste, and devoted to family, the daughters employ different rebellious strategies to reconstruct their identity and salvage what is left of their mothers. Most importantly, however, the narratives capture the girl-child in the process of womaning.

The subject of my essay is not broadly the African novel, but the Nigerian novel of the third generation. Although this generation of novelists continue to attract international acclaim, academic research on their works is still scanty. Apart from numerous reviews and interviews, the first major compilation of academic essays on third-generation Nigerian novelists - to which work Adesanmi and Dunton refer as being "produced by emergent writers who had acquired a creative identity markedly different from that of second generation writers" appeared in a special issue of English in Africa in May 2005, guest edited by Pius Adesanmi and Chris Dunton. The introductory essay by Adesanmi and Dunton accentuates the observation above when they remark that, "little or no scholarship (had yet been done) on the rapidly expanding body of work," ${ }^{2}$ hence the need to devote an entire issue to it. With their dedication of the issue to the discussion of the writings of the third generation, the editors hoped to "signal the entry of the new writing into the arena of African critical discourse." 3 They defended their choice of theme by stating that it provided

a timely legitimation of our initial efforts to bring scholarship to bear on this significant body of writing and a recognition of the fact that more scholars have now turned their attention to this significant corpus of new writing. 4

Encouraged by the success of the special issue of English in Africa devoted to the third generation Nigerian novelists, the editors collaborated on a second such issue, but this time the project was published in Research in African Literatures three years later. They declared that "the new Nigerian novel does exhibit distinctive features, in terms of scope of characterization, thematic and formal characteristics...”

This article, therefore, examines three third generation Nigerian novels, Chimamanda Adichie's Purple Hibiscus, Unoma Azuah Sky High-Flames and Sefi

1. Pius Adesanmi and Chris Dunton, "Nigeria's Third Generation Writing: Historiography and Preliminary Theoretical Considerations," English in Africa 32.1 (2005) 7-19, p. 7.

2. Adesanmi and Dunton, p. 7.

3. Adesanmi and Dunton, p. 7 .

4. Adesanmi and Dunton, p. 8.

5. "Introduction: Everything Good is Raining: Provisional Notes on the Nigerian Novel of the Third Generation," Research in African Literatures 39.2 (2008) vii-xii. 
Atta's Everything Good Will Come as Bildungsroman and demonstrates how the writers have altered the traditional form of the genre to account for the Nigerian experience. The existential aspects of the novels and the progressive metamorphosis of the characters from ignorance to cognition aptly illustrate that the three novels purposively selected for analysis are Bildungsromane, novels of growth and education, and that one of the major determinants of a successful narrative of growth is change.

Ebele Eko identifies the experience of growing up as a major trait in the novels of the third generation of Nigerian novelists; she opines that they are actually describing the "world around them, the events of their growing-up years." 6 Madalaine Hron also argues that the "protagonists of most of these recent Nigerian texts ... are all children or adolescents." 7 Besides the novels being narratives of growth, they exhibit an autobiographical propensity. One of the peculiarities of the Bildungsroman, according to David Miles, is that "there lives in the confessor (protagonist) a painful awareness of change and growth, precisely the awareness that lies at the center of the Bidungsroman." ${ }^{8}$ Chikwenye Ogunyemi, elaborates further on the traits of a Bildungsroman when she suggests that it "educates while narrating the story of another's education. Interestingly therefore, both the hero and the reader benefit from this education." 9

The study associates the Bildungsroman with the growth process of a male character who achieves a harmonious relationship with his social surroundings after a more or less conflictive process of acculturation ${ }^{10}$ it is the sort of novel in which the main protagonist develops his personality throughout the narrative in the key life stages from adolescence to maturity. Nadal M. Al-Mousa defines the Bildungsroman as a type of novel in which action hinges on the fortunes of an ambitious young hero as he struggles to live up to his poetic goals against the negative forces of prosaic reality. The typical hero in the novels of development is

6. Ebele Eko, "Nigerian Literature of the 21st Century: New Voices, New Challenges," Journal of the Annual International Conference on African Literature and English Language 4 (2006) 43-54, p. 45.

7. Madelaine Hron, "Ora na-azu nwa: The Figure of the Child in Third-Generation Novels," Research in African Literatures 39.2 (2008) 27-47, pp. 27-28.

8. D. H. Miles, "The Picaro's Journey to the Confessional: The Changing Image of the Hero in the German Bildungsroman," PMLA 89 (October 1974), p. 981.

9. O. Chikwenye Ogunyemi, "Ralph Ellison's Invisible Man as a Novel of Growth," Nigerian Journal of the Humanities 4 (1980) 5-15, p. 15.

10. Maria Karafilis, "Crossing the Borders of Genre: Revisions of the Bildungsroman in Sandra Cisnero's The House on Mango Street and Jamaica Kincaid's Annie John,” The Journal of the Midwest Modern Language Association 31.2. (1998) 63-78, p. 63. 
a male who "grows up in a humble family in the provinces, but, endowed with an adventurous spirit, leaves home to seek his fortune and realize his ambitions." 11

However, Mikhail Bakhtin argues that the Bildungsroman presents to the reader "the image of man in the process of becoming"; ${ }^{12}$ and situates its protagonist on the threshold between different historical eras. "[The hero] emerges along with the world and he reflects the historical emergences of the world itself." ${ }^{13}$

The essential characteristic of classical Bildungromane is the depiction of a young protagonist growing toward the ability to live in society: "The young man must encounter life, and be formed in that encounter." 14 The prototypical example of the form, according to Mitchell's account, is Goethe's Wilhelm Meister, which portrays a young man's progression toward fitting into bourgeois German society. Consequently, at the end of the protagonist's journeys he is eventually reconciled with the society. My intention in this article is therefore to demonstrate that while the protagonists of the purposively selected text, Adichie's Purple Hibiscus ${ }^{15}$ and the other two mentioned above possess the major features of the classical Bildungsroman protagonist, they do not develop in quite the same way. Adichie's novel shows the protagonist growing apart from society especially her father's standards. As she journeys on, the possibility of her integration into her father's world recedes. This is where the Nigerian variant of the form runs counter to the traditional. I therefore, examine how third generation writers subvert and alter the form in an African context to assert that growth as a universal human experience differs according to contexts and the space where it is negotiated. The paper concentrates mainly on Adichie's Purple Hibiscus, but I shall make passing remarks on Azuah's Sky-High Flames ${ }^{16}$ and Atta's Everything Good Will Come, ${ }^{17}$ not specifically for the purpose of intertextuality, but to demonstrate how these novels belong to the same tradition.

11. Nadal M. Al-Mousa, "The Arabic Bildungsroman: A Generic Appraisal," International Journal of Middle East Studies 25.2 (1993) 223-240, p. 223.

12. M. M. Bakhtin, "The Bildungsroman and Its Significance in the History of Realism (Toward a Historical typology of the Novel)," Speech Genres and Other Late Essays, ed. Caryl Emerson and Michael Holquist, trans. Vern W. McGee (Austin: University of Texas Press, 1986), p. 19.

13. Bakhtin, p. 23.

14. Breon Mitchell, "A Portrait and the Bildungsroman Tradition," in Approaches to Joyce's Portrait: Ten Essays, ed. Thomas F. Staley and Bernard Benstock (Pittsburgh: University of Pittsburgh Press, 1976), 61-76, p. 62.

15. Chimamanda Adichie, Purple Hibiscus (Lagos: Farafina, 2004).

16. Unuma Azuah, Sky-High Flames (Baltimore: Publishamerica, 2005).

17. Sefi Atta, Everything Good Will Come (Lagos: Farafina, 2005). 
Adichie's Purple Hibiscus begins in medias res, realized through flashback. The novel charts the physical and psychological development of the protagonist, Kambili, and her brother Jaja. Their development designates their struggle to define themselves beyond the stiffened and funless world their fundamentalist father has designed for them. Eugene Achike is a wealthy and sensitive capitalist, but his wealth does not translate into domestic bliss for his children and wife. His wealth obviously becomes a damaging influence on the psyche of his family. The narrative is woven around Palm Sunday, yet the development of the protagonist and her brother is symbolically influenced by the spatial settings of the text - their home in Enugu, school, church and Nsukka. The latter has a transformative effect on their developmental process. Adichie describes her setting with unpretentious fidelity. Kambili's home is very typical of children from the aristocratic class, yet they are empty psychologically. Kambili is thus alienated socially, culturally and psychologically from everyone around her, except her brother. The most fundamental problem associated with this character is her consistent loss of perspective. Kambili is not just divided through the unconscious or alienated by the 'myth of the modern,' the loss of natural self; like most modernist protagonists, Kambili is unable to effortlessly identify with her immediate environment. Thus, she is fragmented most importantly through suppressed emotional sensation and psychological drive and what Mary Lou Emery describes as "eclipsed geo-cultural locations." ${ }^{18}$ Kambili’s home is wild and grand, but menacing. It lacks almost nothing yet it overwhelms and inundates her psychological development rather than elevating and animating it. In the first couple of pages one can hardly discern that the Achike home is characterized by the fear generated from Eugene's brutishness because the protagonist appears not to want to state that aspect of family life. One could mistake the children's reticence for moral order. The protagonist and her brother behave as if silence were the arid motto, the abiding philosophy of the family.

Kambili's father Eugene is a highly contradictory character. He appears to be very successful, hardworking, devoutly religious and devoted to his family. Within the walls of the home, however, the family knows him differently and, as the novel unfolds, his obsessive religiosity is unmasked as bigotry and violence.

Eugene is a religious bigot, whose beliefs are founded on exaggeratedly strict Catholic observance. His over-zealous attitude and clipped religious tones overpower the other members of his family. On the other hand, he works hard to ensure that his family lacks nothing. His houses are capacious yet stifling, and the bedrooms are very spacious yet stuffy. Kambili's description of the contrast between their commodious

18. Mary Lou Emery, Jean Rhys at "World's End”: Novels of Colonial and Sexual Exile (Austin: University of Texas Press, 1990), p. 16. 
apartment and its airlessness is telling: "Although our spacious dining room gave way to an even wider living room, I felt suffocated" (7). Coupled with Eugene's overbearing temperament, the suffocating apartment is devoid of life and is isolated. Eugene's brutishness, which has made the apartment unaccommodating will no doubt extinguish any seeming fire of growth ignited in the protagonist:

The compound walls, topped by coiled electric wires, were so high I could not see the cars driving by on our street. It was early rainy season, and the frangipani trees planted next to the walls already filled the yard with the sickly - sweet scent of their flowers. ${ }^{19}$

Kambili, like the true protagonist of a female Bildungsroman exhibits a sense of 'awakening,' which includes the recognition and acceptance of her limitations. If the psychological, cultural and the religio-graphic limitations of Kambili are summed up, what emerges is a deafening silence. Invariably the most important aspect of her transition or rites of passage is the quest for voice. If she is to attain voice, she must transcend and traverse her geographical limitations.

Eugene owns a conglomerate which includes a publishing house reputed for its astuteness and unbiased reportage of the Nigerian political situation and above all its antipathetic posture or stance toward the virulent political temperament of the military regime in Nigeria. He urges his editor, Ade Coker, to ensure that The Standard speaks out, yet his wife and children's voices are shriveling by the day because of the air of machismo around the house. Silence in Eugene's home is magnified to the extent that it could be touched. The function of Kambili's tongue is constricted so that her struggle to express herself usually terminates with a stutter, making her classmates observe her with familiarity tinged with contempt. Because of her inability to make her tongue function in school she is labeled a "backyard snob." ${ }^{20}$ To aggravate her plight, when the closing bell rings, she dashes off to her father's waiting car without exchanging pleasantries with her classmates before she is chauffeurdriven home. Her classmates interpret this as aristocratic arrogance. They are unaware that her life is dictated and regulated by a schedule imprinted on her psyche. Eugene's sense of production evidences his personality as a capitalist. From time to time, he comes home with new products from his factories to be assessed by his reticent family, which has become so dopey in its pathetic state of taciturnity, created by his phallocentricism. This phallic and capitalist arrogance is extended to Kambili's education. Coupled with the sickening and choking home characterized by her father's sense of material acquisition, her education begins to lack creativity and

19. Adichie, p. 19.

20. Adichie, p. 53. 


\section{OGAGA OKUYADE}

enchantment. Both her home and school become prisons for her, as she slips down the academic ladder. The kind of educational system Eugene wants for his children is dehumanizing. He is mechanical in all spheres of life, and as such he condemns and discourages all forms of leisure. When Kambili comes second in her class, rather than encouraging her to put more effort into her academic business, he chides her and asks a mechanical question: "How many heads has Chinwe Jideze? The girl who beat her to second position" (Emphasis mine). ${ }^{21}$ He goes further and presents a mirror to Kambili to ascertain the number of heads she has, and for fear of being tortured Kambili devises a new method of studying:

It was like balancing a sack of gravel on my head everyday at school and not being allowed to steady it with my hand. I still saw the print in my textbooks as red blur, still saw my baby brother's spirit strung together by narrow lines of blood. I memorized what the teachers said because I knew my textbooks would not make sense if I tried to study later. After every test, a tough lump like poorly made fufu formed in my throat and stayed there until our exercise books come back. ${ }^{22}$

Eugene's educational standard is unnecessarily strict; it has no room for humanistic development, reminiscent of the school in Dickens' Coke Town, in Hard Times where students are to be taught facts and nothing but facts. Little wonder Kambili turns the entire academic enterprise into cramming and calculation. Eugene's educational standards stress the training of the intellect without any complimentary ties with the emotion and imagination. To him human reason is important. The reduction of Kambili's life to facts and figures subjects her to mental torture. As the narrative develops one notices varied forms of silence. Kambili, Jaja and their mother speak with their spirit. Sometimes they converse with their eyes. Kambili's mother hardly talks; when she does, it is in monosyllables. Pauline Ada Uwakweh observes:

Silencing comprises all imposed restrictions on women's social being, thinking and expression that are religiously or culturally sanctioned. As a patriarchal weapon of control, it is used by the dominant male structure on the subordinate or mutual female structure. ${ }^{23}$

21. Adichie, p. 46.

22. Adichie, p. 52.

23. P. A. Uwakweh, "Debunking Patriarchy: The Liberational Quality of Voicing in Tsitsi Dangarembga's Nervous Conditions," Research in African Literatures 26.1 (1995) 75-84, p. 75 . 
In the novel silencing is not only a mechanism or weapon of patriarchal control, but of domestic servitude. The children and their mother devise means of survival within the suffocating space called their home. One of the strategies is the timid silence with which she observes situations and the other is a filial bonding. Through bonding, mother and children are able to survive the domestic quagmire and the prescriptions of the religious zealotry of their father. From all indications, Kambili is almost orphaned though her parents are alive. Her father is too mechanical to help her realize her dreams and her mother too docile to be her role model. She never stands firm enough to protect her children. It becomes obvious that Kambili wishes to escape from the confining patriarchal scripts of her home into a space of "private enjoyment." 24

Kambili and Jaja's development is impaired by their psychological instability. They are deprived of any outlet for emotional life except for themselves. The constrictions and deprivations of Eugene's religious philosophy strengthen the bond even more, because when confronted with any form of adversity, they look inwards. Their homes at Enugu and Aba become a fortress for them and at the same time a symbol of vitiation. Both spaces become the site where they shield the realities of their condition and pretend all is well. Thus the homes of others, especially their well-wishers who admire them from a distance, are a symbol of familial bliss and contentment, but for the Achikes "home" provides a cover. While others envy them, they remain overwhelmed by the domineering force of their home. Even within this circumscribed space, Kambili continues her quest to find her voice through eavesdropping. She tries to make sense of her father's conversation with his guests whenever they call. The journey towards the retrieval of her voice begins with what would have been the normal ritual of silence during the Christmas celebration if her aunt Ifeoma had not shown up with her family. The conservative mindset of their father makes them regard anything that he labels 'evil' as abominable to them without any rational or dialectical questioning. Though a Catholic like Kambili's father, aunt Ifeoma initiates the process of Kambili's liberation.

The character of Ifeoma has a threefold effect on Kambili. She is first of all the maternal figure who offers guidance to Kambili. She helps Kambili distinguish between right and wrong through her religious faith, and she helps her find her rhythm and balance in a society that is unbalanced by the asymmetric gender configuration. Second, Kambili sees her as a woman who is self-reliant in a maledominated society. Third, she has the ability to father and mother her children. She plays these roles so well that her children hardly miss their dead father. Through

24. G. Sanborn, "Keeping Her Distance: Cisneros, Dickenson and the Politics of Private Enjoyment," PLMA 116(5) (2001) 1334-1348, p. 1334. 
this character, Kambili begins her initiation into womanhood. It is in her house that Kambili learns the tricky domestic business of cooking. Like Enitan in Atta's Everything Good Will Come, Kambili never has the privilege of assessing the culinary site. The kitchen becomes the space where women nurture themselves and others. Kambili retrieves her voice in this marginal space. She is initiated into womanhood in the kitchen; the rites begin with learning to prepare some local delicacies. Madelaine Hron substantiates this position when she writes that:

It is only when Kambili herself learns to cook and prepare traditional Igbo dishes that she breaks away from the fabricated sweetness of her childhood and gains agency as a woman. At first Kambili does not even know how to handle a yam (134); Aunt Ifeoma must show her how to soak her hands in water and slide the skin off (165). Kambili's hand-soaking initiation in Ifeoma's kitchen thus contrasts starkly with that of Eugene, whose behaviour was conditioned by a missionary's basin of scalding water. Moreover, Kambili's entry into language, her first voiced rebuttal in Nsukka (176), also concerns food preparation; she demands to learn how prepare orah soup [sic]. ${ }^{25}$

The kitchen becomes the site of Kambili's redemption because it is the locale where women must become what they must be and learn the art of feminine expression and take total control of their existence.

"Things actually started to fall apart," ${ }^{26}$ when Kambili embarked on the trip to Nsukka. On arrival at Nsukka, Kambili is stunned by the polarity between the frolicking temperament that pervades the cramped apartment there and their forlorn existence even in the midst of everything that should make life luxurious. Kambili becomes confused by the untrammeled grace with which everybody carries themselves in the house. Her inability to comprehend this disposition makes her dissolve even further into silence.

For Kambili, Nsukka does not only represent a town where her aunt lives, but acts as a symbol of liberty, as the concluding chapter evidences. Her teenage development becomes complete in this town because for the very first time her mouth performs almost all the functions associated with it. She smiles, talks, cries, laughs, jokes and sings. Through Ifeoma, Kambili discovers her grandfather Papa Nnukwu's sense of pantheism, as she watches him from a distance commune with his [G]ods an occasion which proves the old man a better believer, who understands the intricate geometry of religion, most especially, the relationship between [G]ods and

25. Hron, p. 34.

26. Adichie, p. 1. 
man, thereby disproving and debunking her father's stony fundamentalism. For the very first time she lives a life that is not dictated by a schedule, though the items in the schedule are engraved in her heart, Ifeoma consigns her nephew's and niece's schedules and customizes them to her world - a world characterized by the application of the commonest of senses.

As she develops psychologically under the tutelage of Father Amadi, she commits a cardinal sin, through a Freudian slip. Midway through her journey or apprenticeship she falls in love with the priest. At this point she does not know the implications and consequences of this psychic emotional drive. Father Amadi is perhaps the only man outside her family circle who has been so close to her. As she matures physically and mentally, her emotion builds up as well, reaching its climax with her sensational pronouncement of her love for the priest. This invariably becomes a vibrant statement of her first access to freedom of speech.

Eugene notices remarkable changes in his children as they settle down after their journey to Nsukka. One such change is Jaja's modest but unprecedented demand for the key to his room. Eugene is astounded by this demand and decides to take pragmatic and overt steps to ensure that his children return to his doctrinaire standards. This leads to a cleansing ritual, which will purge and purify Jaja and Kambili of the sinful dust of Nsukka and the pagan temperament of the air of Ifeoma's home. Eugene bathes Kambili's feet in hot water, completely disregarding her screams of pain. The ritual yields a less than proportionate return because it fails to produce the elutriating effects Eugene desires. The children have brought two items from their aunt's; Jaja brings seeds of purple hibiscus while Kambili brings the uncompleted painting of their grandfather. Both items represent freedom from the rigid and despairing lifestyle of their father's world, and enable them to sustain a steady link with their aunt's airy world en route for liberation. With these prized possessions they hope never to plunge within the confines of frustration, disillusionment, alienation, and the existential solitude of the world they know too well. The items will help them fill the vacuum created in their lives. Her father suddenly discovers Kambili's painting as she and her brother are admiring their grandfather. Like the extremist that he is, Eugene takes the painting from his children, who both claim ownership of it at the same time. Stunned by this development, Eugene destroys the painting, and Kambili is unable to restrain herself. She is not ready to watch her father tear something she holds sacred from her just like that, although she has remained silent all her life. However, since she has retrieved her voice, she is unwilling to observe her father truncate the stable transition of her development, which the painting will help her realize even within the circumscribed radius of her father's walls. If the painting for Kambili symbolizes freedom and at the same time the remains of her grandfather, with whom she never connected 
while he was alive, it represents something ugly for Eugene and it must be destroyed. For him it represents a connection to a past which is now a threat to his empire. She begins to reassemble the pieces of painting with alacrity and observes her father with a defiant air, an unequivocal expression of rejection, condemnation and disintegration of the unproductive upbringing that her father had given her. The furtiveness with which she handles the painting embarrasses everything her father stands for. He is stunned by the confutation of his conservative religious standards - an occasion where he is completely subdued by the first shocking evidence of the result of his rigid religious matrix; Kambili's handling of the pieces of the painting symbolizes the collapse of her father's system. Rather than realize and admit that his philosophy is inhuman and inefficacious, with a doleful expression on his face he degenerates into an uncontrollable fit of anger and slaps Kambili into a state of unconsciousness. The trip to Nsukka initiates a domino effect in the developmental process of Kambili and Jaja.

Through this incident Kambili succeeds in breaking out of the social and religious silence of her earlier life. She declines to acquiesce to the status quo - escaping from her entrapment, by debunking her father's authority, a definitive statement of rebellion against the phallocentric and autocratic set-up.

At the concluding chapter, she plays Fela tapes without any form of fear of contravening standards. She issues cheques to people as her will moves her. Fela is a symbol of freedom of speech, fair play and justice. While alive, his bohemian lifestyle marked him out whenever he was on stage performing. He was the Afrobeat maestro who used his music to resist and contest several Nigerian governments for their oppressive and corrupt tendencies. To the government, Fela was a marksman whose musical shots were always on target - he spoke to the pains of the people and lashed out at the government for their moral depravity. Before his death, he suffered numerous incarcerations, but each time he returned and continued his battles with the government; nothing ever deterred him from speaking out. When Kambili visits her aunt on the first occasion, the kind of tapes Amaka played are abominable to Kambili. Since she is now free not because of her father's death, but because she has reached the pinnacle of her development, she can easily differentiate between good and bad. She does not need to be goaded to make decisions. Kambili discovers her selfhood as she evolves from what she has learnt at Nsukka and puts to use that knowledge to build her own worth. Ifeoma creates the avenue for Kambili to stimulate her self-worth. The reader can now begin to follow the growth of Kambili as she moves forward with her internal epiphanic awakening and watch her as she learns to be a mature woman, an aspect of the female Bildungsroman. The narrative centers around a quest Kambili embarks upon for the restoration of her dignity, encapsulated in the act of voicing. She discovers herself at Nsukka and coincidentally, the 
motto of the University of Nigeria Nsukka ${ }^{27}$ is: To Restore the Dignity of Man. The entire narrative is tightly woven around this motto, which endows the novel with a structural balance between content and form.

In Unoma Azuah's Sky-High Flames, she gives an account of the childhood of Ofunne, the main character of the novel. In the first chapters, Azuah paints an extremely vivid picture of childhood in a rural setting. The reader is able to enter Ofunne's mind and see the world through the eyes of a child. The novel begins with a startling announcement of the exigent and exacting responsibilities of occupying the privileged position of the eldest child of the home in a rural African society:

I was almost driven to hate my parents. My father never approved of anything I did. He felt he knew what was best for me, and my mother picked on me like a bird with a sharp beak. As the first daughter, I've always had to cater to [sic] everyone's needs but any minute spent by myself was called daydreaming. ${ }^{2} 8$

From a very tender age Ofunne's destiny has been decided. She is to remain docile and inactive in the culinary site where her parents continue to keep her in a supine position. Her upbringing is strictly domestic, in order that she should fit the office of a chattel or become the object of the evening amusement of some man in the future. Her parents would do anything to ensure that the course to her destiny is not truncated. She becomes entrapped at a very tender age. Although her parents' plans for her to become a fulfilled woman are a recipe for her disaster, she psychologically maps out strategies for her liberation from the imposed state of inertia that her parents intend to plunge her into. The path to freedom from her entrapment is education. According to F. M. L. Thompson, "an education was a passport to respectability and a necessary ticket for entry to many trades." ${ }^{29}$ Hazel Carby amplifies Thompson's position on the importance of education, Carby strongly believes that the education of females will prompt social changes and move women into a different sphere where they are no longer subjected to domestic positions which outrageously demonstrate the inefficient use of human resources, which in turn leaves the potentials of women grossly untapped. This is a goal Ofunne wants to achieve. Education becomes the prized commodity that will redeem women from being "confined to a domestic sphere." 30 Regardless of her under-privileged status as the eldest daughter in a rural family, she asserts that, "I wanted to be well edu-

27. The first University in Eastern Nigeria, established in 1960.

28. Azuah, p. 7.

29. F. M. L. Thompson, The Rise of the Respectable: A Social History of Victorian Britain 1830-1900 (Cambridge, MA: Harvard UP, 1988), p. 136.

30. Hazel V. Carby, Reconstructing Womanhood (New York: Oxford UP, 1987), p. 99. 


\section{OGAGA OKUYADE}

cated with a high school certificate. I wanted to become a teacher and get married to the man of my dream." ${ }^{1}$

Azuah evokes the nervous tension of village life and depicts the dramas of everyday existence in a cross-section of the society - a society that is psychologised, people are not told what to do; they know what to do, because the gender configuration becomes the central plank of cultural life. Azuah's exploration of the burden of womanhood comes very close to Tsitsi Dangarembga's Nervous Conditions. ${ }^{2}$ Ofunne at a very tender age is able to resist attempts of the phallocentric precepts of her society to reduce her to a marginal status, when she triumphs over the young boys who are supposed to be Iloba's [Ofunne's younger brother] age mates at the river. The incidence dramatizes signs of incipient determination to overcome her marginal status. From the beginning of the novel to when she is sold off into marriage one will find many examples of attempts to socialize her at an early age into feminine roles, which will in turn render her uncreative, and docile. She is saddled with the responsibility of the domesticity of her home. If she fails in her task to get the family going domestically she becomes accountable for whatever misery emanates from that failure. Thus, Iloba holds her responsible for his being late at school. By the time Ofunne leaves home for school, she has been partially domesticated; partially because her marginal status and the food office fail to leaven her life as a woman. Hence when her entrance exam results indicate that she has passed, she abandons the homestead with immediate alacrity.

In contrast to the Bildungsroman, in which the male leaves home to "slay the dragon," Felski opines that "the female on a journey of self-discovery seeks surroundings that aren't a threat to her," ${ }_{33}$ a domain that echoes rather than threatens her sense of self. It should also be noted that in the female Bildungsroman the protagonist never runs away, if she embarks on any physical journey for selfrediscovery. It is usually initiated by family members or friends. She hardly escapes because she usually comes back to the space of her limitation. Ifeoma creates the avenue for Kambili's journey to Enugu, Enitan's parents decide to send her abroad because of her involvement in Sheri's rape and Ofunne leaves her home for the sole purpose of acquiring education.

School for Ofunne becomes a place of becoming. She is the favourite among the teachers and students. Ofunne gradually learns to deal with the new environment. However, she is seized by occasional fits of eccentricity, which propel her into exciting troubles with fellow students or the head teacher of the school. Sister Dolan, the

31. Azuah, p. 7.

32. Tsitsi Dangarembga, Nervous Conditions (New York: Seal Press, 1988).

33. Rita Felski, Beyond Feminist Aesthetics (Cambridge, MA: Harvard UP, 1989), p. 135. 
head teacher, becomes the symbol of inspiration for Ofunne. She is a true matriarch who understands the exuberance of teenagers and how to brace up to the challenges of that phase of human development. She is a strong role model for Ofunne as she begins her transition from childhood to womanhood.

Ofunne's future suffers a setback with the indisposition of her mother. She is cornered into marriage and her quest for education is truncated as she follows Oko to Kaduna to live as a child-wife, where she enters and sustains herself in the social space of female silence once again. She continues to appear to disappear. Her school days seem to be the most eloquent and vibrant because they were the path to her liberation. Ofunne is stripped of her rights, which are supposed to be parental care and guidance. She is found guilty of being herself and rendered invisible. Ofunne suffers more at the hands of her parents, as Philip Collins points out, "the adult world is generally hostile, vicious, uncomprehending or indifferent, or the child had to minister to instead of being supported by it." 34 Ofunne, for instance, is brought up by parents whose intention is to marry her off when a suitor comes calling, regardless of her age and ambitions. Kambili is beaten by her father; Enitan's parents are torn apart by matrimonial feuding so that she hardly identifies with either of them. All those who should be nurturing them into womanhood constantly demoralize these female characters, who are not stably growing up or being brought up, but are only tumbling up.

Ofunne's deflowering after her mock-marriage becomes an initiation from girlhood into womanhood; she becomes adaptable to matrimonial life with ease immediately she is deflowered, regardless of Oko's aberrant behaviour. However, Oko's promiscuity is abhorrent to her sense of decency. Matrimony for Ofunne gradually becomes an arduous enterprise because her husband refuses to make the enterprise pleasurable. She becomes convinced of Oko's carnality and his unbridled lubricity, as she reminisces on the steady gaze Oko gave her ample-breasted friend Uka, on one of his visits to her school. The gaze is not just an amorous advance, but also an amplification of the degree of his promiscuity. At this point, the novel floats around the existential themes of pain and exile. Out of frustration, Ofunne tries to return to the geography of her childhood through letters, when her state of loneliness and alienation deepens.

Taking her own expectations - regulated by her own society, which is patriarchal - into consideration, Ofunne's circumstances only serve to sustain her growing lack of identity. She refuses to find tranquility in the only space in which society locates her; the kitchen where she spent her childhood. As Oko's wife, she has no choice but to take over the kitchen, as it becomes her private domain. She circum-

34. Philip Collins, Dickens and Education (New York: St. Martin's Press, 1964), p. 182. 


\section{OGAGA OKUYADE}

vents the rules of the kitchen and attains power. Whenever Oko defaults, Ofunne regresses into a defening silence and aloneness, which become frustrating to Oko. This is one of the strategies Ofunne employs to check her philandering husband. The other strategy is the use of her culinary power, which she uses to curb her husband's excesses. When he misbehaves, Ofunne refuses to cook for him. The kitchen becomes the hub for action in the novel, and it is from there that Ofunne attracts her husband's attention. In Purple Hibiscus, Kambili's mother uses it for dangerous ends while Sheri in Everything Good Will Come uses it to control other characters, especially since she is a consummate cook.

As Ofunne's pregnancy nears its term, Oko decides to take her back home. Mariane Hirsch contends that women hardly break family ties as easily as men irrespective of whatever offence is committed against them. Apart from that factor, this return actually contributes to Ofunne's self awakening - returning to the original site of dependency is a momentous step in the process. Hirsch notes that contrary to the classical Bidungsroman, which is linear in nature, the woman's "awakening" is marked by circularity - her need for repetition. 35 Felski substantiates further, that "the heroine must become what she once was, recover an identity which is complete and self-contained, rather than contingent, and historically and socially determined." 36

The novel climaxes as the full irresponsibility of Oko becomes obvious. The literary representation of women in urban environments often functions symbolically as loss of innocence - the pure daughter and mother of the village is reduced to a prostitute. Ofunne's case belies the above norm, because at the time she returns to the village, she is still naïve. Her refusal to allow the medical doctor to induce birth in order to ease her delivery evidences this. Though Ofunne's child is still-born, she reaches the pinnacle of her development after the delivery. As Oko abandons her at his parents,' she fights her way out of her shackled state as she beats her mother-inlaw up for her falsehood. Ofunne's development peaks as she replaces her Catholic God as her crisis lingers. Ofunne fails in every attempt to find meaning and purpose in her life. She is tormented by an existential discontent and disruption of selfhood, stemming from her privileged marginal position as eldest daughter. Ofunne fails to create a purpose or an order in her life, and she abandons her belief in a God that denies her the possibility of such a purpose or order. Her apprenticeship becomes whole as she replaces her Catholic God. She gains physical and spiritual freedom as

35. Marianne Hirsch, "The Novel of Formation as Genre: Between Great Expectations and Lost Illusions," Genre 12 (1979) 293-311, p. 46.

36. Rita Felski, "The Novel of Self-Discovery: A Necessary Fiction?" Southern Review 19 (1986) 131-141, p. 141 
she returns home and presents herself, empty, before Onishe the water goddess. This scene eloquently dramatizes Ofunne's sense of religion. One may confuse her intentions here. It is not the locale that dictates her spiritual cum religious loyalty. She abandons the Christian God, which is an extension of male dominance. Her parents gave her to Oko not only because they wanted money to meet their needs, but they also feel the Okolos are a good Catholic family. Ofunne abandons matrimony because it becomes the symbol of her vitiation. She wants to be educated but her parents sold her off in marriage. Her husband promises to allow her to continue her schooling when they arrive at Kaduna, but she never goes beyond the marginal border of the kitchen and the docile space where she hawks fish. She finally decides to find Sister Dolan and start afresh. She becomes epiphenized in a state of trance as she submits herself nude before Onishe.

After the regression and the return from what Obioma Nnaemeka describes as their "orphic journeys," ${ }_{77}$ these female characters become whole; armed and determined with the resolution to make functional the lessons they have learnt in the process of their Bildung and journeys, in a self-fulfilling manner. These female writers achieve numerous goals in exhuming an almost forgotten genre to make constructive and empowering statements. The Bildungsroman has proven to be a formidable and unparalleled success as a template by which writers and critics alike can understand Nigerian society and Africa at large. But most importantly, the form has become a postcolonial index for calibrating the growth and development of the African continent with that of the protagonists of these narratives.

Atta's Everything Good Will Come maps the protagonist Enitan's journey to womanhood. However, her mother is more of a Victorian woman whose cardinal responsibility is restricted to home making and building. For Enitan to attain individuation she has to grow against her mother's standard. Enitan's struggle for feminine subjectivity becomes complicated as her mother becomes blindly religious because of the death of Enitan's brother. The mother becomes dominating and manipulative. She insists on strict domestic rules which articulate the accepted social conventions of gender and ethnicity and Enitan must conform to these standards. The rape of Sheri, Enitan's friend, further complicates the latter's struggle for individuation.

The function of the Bildungsroman in shaping the Bildung of its readers is intimately connected to nation-building in Sefi Atta's Everything Good Will Come. Like institutionalized education, Atta uses the Bildungsroman as a strategy for de-

37. Nnaemeka, Obioma, "From Orality to Writing: African Women Writers and the (Re)Inscription of Womanhood," Research in African Literatures 25.4 (1994) 137-157, p. 154 . 
veloping national identity and promoting social cohesion, by endorsing and perpetuating specific ideologies. In Reconstructing Children: Strategies of Reading for culture and Gender in the Spanish American Bildungsroman, Julia Kushigian argues that "the goal of the German (Bildungsroman) was to inspire the middle class to a life of public service, with obvious benefits for the state," 38 thus, the history of the Bildungsroman tradition is connected to nation-building and the socialization of 'good' citizens.

Atta focuses more on the dialogue around identity and its manifestations for nation building in Everything Good Will Come. The basic argument, therefore, rests on the fact that the perspective where the female postcolonial Bildungsroman diverges from the conventional template illustrates the effects of gender, race and postcolonialism on the production of both individual and national identity. $\mathrm{Ku}-$ shigian argues that "[t]he female or marginalized, Bildungsroman may reject society's rules in an effort to redefine society through culture and gender." 39 While a male European model for Bildung has set a standard against which both female and postcolonial novels of development have been measured, understanding nontraditional Bildungsroman as entities unto themselves rather than as mere mimicry will help demonstrate the meaning of these alternative stories.

Musing on her difficult journey of womaning, Enitan ponders on how she "called out to her voice" (Everything).40 The "voice" to which she is calling refers primarily to her right to speak herself for herself - to be listened to and to be considered a person worthy to be listened to. However, like Kambili, she first needs to gain access to a language and voice, before she can performatively speak herself. As is the case with Kambili, the process of finding voice and gender development mutually inform each other. Therefore, the assertion of one's sexual independence and negotiating one's sexuality provides the feminine subject with the necessary agency for accessing language and voice. As Enitan acquires a language her voice becomes functional as she begins to contest dominant positions both in the familial/private domain and the public/social space. Language invariably gives her the agency to question things dialectically and construct an identity for herself.

The essence of language and sexuality as forces of performativity in the process of becoming or womaning is vibrantly expressed in Sheri's rape. Three boys hold her down; gag her, and then execute the act of silencing her through rape. Neither Sheri nor Enitan is able to speak about the event afterwards. Although the incidence

38. J. Kushigian, Reconstructing Childhood: Strategies of Reading for Culture and Gender in Spanish American Bildungsroman (Lewisburg, Pennsylvania: Bucknell UP, 2003), p. 16.

39. Kushigian, p. 36.

40. Atta, p. 179. 
of the rape is chaotic to the psyche of both women, the subject becomes a taboo. Rape can be deconstructed not only as an act that violates feminine sexual autonomy, but also as one that silences or dries up the voice of a woman, leaving her bereft of almost any form of power and agency that she might have had to speak herself. The rape therefore strips Enitan of the power and agency to speak herself, regardless of the fact that the act is not physically performed on her body. Willem Jacobus Smith suggests that "Enitan and Sheri alternate as double and foil of each other." 41 Psychologically, Enitan puts herself in Sheri's position so that it appears as if it is Enitan who is raped. This act of psychic doubling robs Enitan, by implication, of power and agency. This is what makes her obsessed with washing herself after sexual intercourse, and being unable to speak about the incident until many years have passed. Mike Obi is the character who eventually liberates her from the bondage of the rape through a bathing ritual.

Atta's narrative is fascinating because in contrast to the female Bildungsroman protagonist, whose gender identity is formed within the psychodynamics of the familial base, the development of Atta's protagonist is marked by discontinuity. She grows against the standard because her father wants her masculinized. This breach explains her instability in the primordial base, the socio-civic and matrimonial spheres. Atta's narrative, like Adichie's, is a Bildungsroman that conflates the search for an autonomous female identity with the quest for a meaningful national identity. From analysis of texts, it becomes obvious that these narratives do not only celebrate the coming of age of the protagonists, but also articulate the distinctions between the classical Bildungsroman and the African variant of the form. These writers have subverted and altered a western oriented genre to give expression to the politics of identity formation in a postcolonial context. Furthermore, the narration of these novels places primacy on the protagonists as agency, in order to construct the traditional, personal and privatized genre of the Bildungsroman by transforming it into a political scheme, making the personal experiences of the protagonists serve as an index to the larger cultural, socio-historical conditions, and thus the protagonists' personal Bildung becomes inseparable from the political agenda of their nations. Invariably, the growth and development of Nigeria may be calibrated by the growth process of the protagonist.

As noted in the introductory part of this essay, one of the most fascinating features of these texts as Bildungsromane is their point of departure from the traditional variants. The protagonists are unable to conform to the grand dominant

41. Willem Jacobus Smith, Becoming the Third Generation: Negotiating Modern Selves in Nigerian Bildungsromane of the 21st Century, MA Thesis (Stellenbosch University, South Africa, 2009), p. 61. 
standards their societies have constructed for them, and the circumscribed spaces where they are to negotiate their identity and become women frustratingly trapped within the confines of marginal spaces like their mothers. The growth processes of these protagonists exemplify a variation of the Bildungsroman in its contemporary feminist state and offer an alternative to conventional notions of social roles. They articulate the fact that a woman can successfully or unsuccessfully claim the right to be a self-determining individual regardless of patriarchal constraints. They offer a model of resistance to women's oppression. The Nigerian variant of the Bildungsroman articulated in these novels portrays the struggle for individuation and the negotiations of feminine subjectivity, while concurrently depicting the plight of women in a society plagued by the debilitating forces of patriarchy and suggesting alternatives to that plight. 